\title{
REDEFINIG ECONOMIC SYSTEMS AS AN ISLAMIC ECONOMIC SYSTEM
}

\author{
Muhammad Waqas ${ }^{1}$ \\ Faculty of Management Science Institute of Business and Technology Karachi

$$
\text { Imam Uddin }{ }^{2}
$$ \\ Associate professor \\ Institute of Business Management, Karachi \\ Badar Ashfaq ${ }^{3}$ \\ Head Department of Accounting DA School Karachi \\ Rabia Shakir 4 \\ Department of Economics University of Karachi
}

\begin{abstract}
Objective: Need of new economic model has been realized at the international level, as numerous and significant flaws has appeared in both two systems capitalism and socialism, which are becoming great cause for economic crises in almost every economy of the word, in this regard this study has been carried out on the redefining Islamic economics as a new model, that how it can take out those problems and flaws which has appeared in both structure.

Methodology: Islamic economic system doesn't emphasize only on the economic variables it also considers the social variables which has been neglected by both previously and currently practicing systems (socialism and capitalism).current study is a comparative analysis of all said systems.

Findings: It has been also observed that in spite of having great strength to winkle out all the economic problems, without interest how we are able to get the profit and what different types of new loan system that is RIBA free and helpful for getting the good profit. Practical Implication: In Islamic economic system the private property is being debatable. Government or state should be involved in only condition if market is failed to provide public good and education.
\end{abstract}

\section{Key Words: Islamic Economic System, Capitalism, Socialism}

\footnotetext{
* The material presented by the author does not necessarily portray the viewpoint of the editors and the management of the Institute of Business \& Technology (IBT)

$\begin{array}{ll}\mathbf{1} \text { Muhammad Waqas } & : \text { m_waqas74@yahoo.com } \\ \text { 2Imam Uddin } & : \\ \text { 3 Badar Ashfaq } & \vdots \\ \mathbf{4} \text { Rabia Shakir } & :\end{array}$ 


\section{INTRODUCTION}

As we are acquainted with the different economic system of the world and it has been observed that no economic system is perfectly working in order to fulfil the economic requirement and needs of the human being. The needs of human being doesn't confined only with the fulfilment of food, shelter and clothing, they are very much vast in nature as human beings also do many activities for their satisfaction for instance purchasing of property, sale of goods and services, investment, borrowing loans etc.

Under the capitalist domain purchasing of property can be done by public also, as capitalist economic system enunciates about freedom which means no role of state that is market is free to operate, in such system society become materialistic as everyone become engage only achieving their self-interest no one cares about other people of the society which ultimately brings lots of negative impacts and frustration in the society, as ownership of property only get freeze in the one hand of the society, due which economic imbalances appears, which has become major weak point of capitalism.

On the other hand in socialism state or government has power to possess property, general public has deprived from its possession, as all the time situation doesn't remain same, and only by the interference of government situation cannot be resolved successfully.

Capitalism has complete focus on free market system, however socialism has complete focus on that property should be possessed by state only. As we know that economic activities are not related with only one dimension they have multi dimensions, therefore problems of these vital statistics can't be resolved under the umbrella of such economic system which is focused on one direction only.

The Islamic economics has strength to focus on all the directions of the economic activities, as it doesn't discuss about materialism as capitalism does. Islam enunciates equal distribution of goods and services, as Islam does not make people materialistic. It teaches about how to care other's interest as well. Islamic economic system has strength to overcome the weaknesses of both socialism and capitalism.

According to the traditional economics (which pertains to socialism and capitalism) that needs of human beings are unlimited and resources are scarce, whereas Islam signifies that resources are unlimited and needs are limited if we spend our life under the light of Sharia. After the above explanation it has been observed that Islam has resolved the great difficulty of monetarist economics. In other words in the light of Islam resources are abundant and wants are confined and we are ordered to limit our wants.

\subsection{Islamic Economic Strategy}

Islamic economic is the information skill and application of order, a guide of the shariah that control or command of material resource in arrange to provide reparation for an insult to human being and capacity to perform a binding to Allah and the society. 
The Islamic economic system is based on the service and worship of Allah or the supernatural and religion Islam. Islamic economic system is a complete system which provides guidance to human beings in their every aspect of life, it doesn't only discuss about forbiddance of certain deeds but also provides guidance under which we can lead a lawful life for instance Islam gives complete guidance for trade, purchasing of property even it provides assistance on our daily life issues that how we can deal with such problems under the light of Quran.

The Islamic economic strategy has been constructed on three fundamentals.

$\S \quad$ Possession

$\S \quad$ Disposition of affluence

$\S \quad$ Fair distribution of affluence

Islam completely governs the humanity and provides lawful ways for the ownership and contracts which help to take possession and generation of wealth. Such well-defined ways of dealing which make ease for the people to earn money by lawful means and they have freedom to generate affluence as Islam doesn't intrude in the earning of affluence. Hence in Islam the methods of possession and the contracts are given under the light of Sharia.

The notion of disposition of affluence in Islam varies from socialism and capitalism as it has been constructed on the Holy views, which contains moral values. Islam has given two types for the disposition of affluence which are,

$\begin{array}{ll}\S & \text { Primary } \\ \S & \text { Secondary }\end{array}$

In the first type wealth distributes among those people who are directly indulge in the production process with the help of four factors land, labor, capital and organization. The second type also known as redistribution of affluence as it include those people of the society who couldn't contribute in the production process and are also unable to fulfill their needs by themselves for instance children, widows, poor etc. Some primary features of Islamic economic system are written below; $\S \quad$ Belong to Allah all the wealth :

"And give them of the wealth of ALLAH which He has given you."(An Nur:33)"

$\S \quad$ Hoarding of wealth is prohibited:

"And that who hoard up gold and silver and spend where of $\mathrm{He}$ has made you heirs."(AL TAUBA: 34)"

$\S \quad$ Is a duty Circulation of wealth

"Whatsoever Allah may restore unto His messenger is due unto Allah and unto his messengers the orphans and the needy so that it may not be confined to the rich amongst you."(AL HASHR: 7).

In Islamic economic system interest (RIBA) is prohibited because in Islam there is a band on generating money without any economic activity or any other activity which is HALAL in Islam, that money impacts a negative role on the businesses and the family life. In Islamic economic loans and bonds will be issued but only against the assets for those who will generate money from the activity. But RIBA are restricted in 
profit is good for the owner of the business. Normally that transaction was strictly restricted in this system where those items are involved which is HARAM in Islam is for example gambling, tobacco, alcohol etc.

In Islamic economic the best way to reduce the poverty from the economy is called ZAKKAT. It is basically not a tax but it is a kind of tax. The particular amount is deducted from the account of a person who is holding a $7.5 \mathrm{~kg}$ gold, $52 \mathrm{~kg}$ silver and as same amount of price over a whole year. The amount will be deducted as $2.5 \%$ of the ownership as above mentioned. Normally ZAKKAT will be paid to the very poor person of the society, so in this system the reduction of poverty is being planned very well. Because if everyone will pay ZAKKAT to the poor (every year) than the poverty will be eliminated from the society and this is the best way to reduce poverty level from the economy.

Under Islamic Economic system there are three different processes to get the loan for different activities. First one MURABAHA which is loans for customers but these are interest free loan. In this, bank provides a loan for the customer and this is a business contract type agreement. If the prices will increases and for example the partner will break the deal, so bank will support the deal.

Second MUDABARAH, in these investors will offer their capital after getting the complete intonation about the business or project plans; normally investors know how much risks involved in it. But if the palm will successfully making profit than the profit will distributed between the investors and business owners. In another term we can say that it is a co-ownership agreement between invertors and owner of the business.

Last but not the least is SUKUK. In this funds normally not collected by the banks it will collect from the markets and will be signed for a special purpose company. In 1998 SUKUK market collapsed and the Islamic scholar named "TAQI USMANI" was re-design the SUKUK form and include in a repurchase agreement for the date of its maturity.

\section{LITERATURE REVIEW}

Social and market economic system have some negative impact on the society, so the new system is being introduced that is Islamic economic system. But as we all know that any system being developed as fast as society wants. In Islamic economic system, the proper structure is not being still developed, if we are saying that it is being moving toward the proper development than it is acceptable because still the new steps is taking for the improvement of this system. Different researcher has been already done their analysis and they conclude their research in that way.

Islamic economic system is a best system that represents Muslims behaviour in a Muslim society and there are not involve the interest role. The economic system in Islam is role of absolute set of codes for the whole life with this a way of looking in mind always we should be inspect closely analysis is that not realization to isolate the economic system from part of Islam. Because they are connect with one another market 
system are zakat is examine as purifying act, not relevant to economic value and quality. It is the relating to sacred mater attitude the Muslim reflects in life and numerous care for virtue. Islam does not religious convictions in radical changes of interrelation of problem as a consequence change in nature of problem of Islam society maintains in socialism. Religion starts not from of production and man need of life. The obligations of man are of two characters fundamental effort is one of the factor used is changing with a period of time. Islamic economic system is not continuing in actual meaning and permanent set of different standard satisfaction of first, need of kinds. Islamic economic system is the Muslim one who mediates a reaction to the economic a call for fight or to defy of times in this journey to what is useful in achieving as ends according to the Quran and sunnah as well as by solution observation study. The Islamic economic system and market economy includes capitalism socialism and mixed economy's extent economics in high. In other involved control traditional barter economy are gift in participatory. Socialism and capitalism as a important a contend system in economic that create circumference the division two century for request capitalism begin to come into existence if the nation capital was instruct to describe the rise economic of the west and socialism control the eastern blocks in government. (Muhammad A. H., 1975).

The Islamic economic system have specified laws that can be obtain from the original sources i.e. Allah firmly decide right and wrong rules of uses, rules of avoidance of extreme actions rules of in restriction and rules of magistrate. The Islamic economic system is immediately advises by Allah Almighty Himself economic theories could be presented if the rule and regulation are adopted. In Islam, the source of information and awareness is fundamental remarkable thing i.e. divine guidance (wary). This research mostly emphasize in Islamic economic system from 300years ago, there was no concept of Islamic and every one has its own limitations but when Islam revealed it shows some restrictions and limitations .every single person, according to Islam is meaning less if the particular person is not provided appropriate freedom to act separately. Therefore takes highest value on individual's freedom of action in every field of human activity such as economic, social, moral, political, religious etc. It also recognized functions of organization, labour, capital and market forces in economic field. The give reasons for debate on two economics centrally growth and planned economy and market state economy. The figured out economy make allowance the plan by government and unionize economic function this activities that find and further the system well being of the nation in general level of output. In market economy whatever manner those private handles move the power by government to authoritatively and resolve. This method is meaning economy of market mechanism tolerates the demand and supply equal force played a important role in economy is capitalism. (Ismail \& Arshad, 2009).

According to his study that show in the importance sections that this comprehensive crises of capitalism is very plugged in most common topic of the traditional Islamic though in the after first section we make understood that period of Islamic economic system is always a true representation of spirit of the time and relation with the occurring challenges Islamic system has to face that Islamic economy adjust the focus of most extent banking system and finance. A new Islamic though come out in view around the 
concept of Islamic governance. With out challenge the fundamental pretension that understands capitalism show how to conform capitalism it Islamic economic system. The capitalism and easy find out an alternative system and Islamic think has a fortune say on issue to solution. To continue in existence reason common welfare of nation and Islamic problem has been focused Islamic economic system. It was holding the attends the world economy was section indifferent region concern. But world of Islamic is now involving several races in world. The economic system in Islam as placed in opposition to alternative moral realize does not the existence of interest play is prohibit but also against and resist speculative activities an outer layer or envelope in production of unlawful product and adulteration the equip of Islam recognize alternative investment and finance avenues structure include is that sukuk, ijarah, musharaka and mudarabah. (Moisseron \& Teulon ).

Islamic economic system is systems which define the overall activities of the life and it is a functional component and Islam discusses the overall order. In Islamic economic system, role of profit and loss is present and motivate to engage in risk taking activities in the economy. The important part of the Islamic financial institution is takeup. In this aspect there is no role of interest. It works on the basis of non interest and for economic growth it provides funds on the basis of Islamic manner and it also gives insured product most of the business person and individual to run their business and to secure. The aim is to grow up maqasid and well being of human and these institutions work under the Islamic frame work. The aim of Islamic economic system is to fulfil basic needs redistribution and social justification Islamic economic system attempt policies. These policies should increase the seek of knowledge because of this productivity will also grow up and transparency in government will be develop. These policies also growing up the equity of intra and intergeneration .in these policies, opportunities are limited. The market economy is consider economic growth and development is a state by integral impossible to divide or separate by man development establishment the base need and the typical and value of frame work of Islamic system this involved the most important that remove interest by business the record of transacting of organization is haram overlook the validity of agreement economy. (Asutay, 2007).

In Malaysia, new economic model (NEM) is being established in 30 march 2010. Many differences have been noticed yet. In Islamic economic system the best example or the best plan is being consider that, in this system the poverty reduction plan was very excellent and if we follow that plan, so poverty will definitely be reduced or minimized after some years. In this system the values and moral values is being sets very well. The concept of justice, equality, brotherhood and benevolence and empathy is clearly defined in this system. Islamic economic system has some different rules and regulation, this system is very different from that system which was made by humans. This system is being organized with help of the HOLY book QURAN and the SUNNAH of our beloved prophet MUHAMMAD (S.A.W.W). In this system the goals and objectives are much different from the social market economy. (Rahim, 2011).

The Islamic economic system is mostly related about Islamic management tools and organizations. There are some tools on Islamic rather than convential. Islamic 
economics is not about the forbids of relied goods and services. Islamic economic system is a different system from socialism, capitalism and mixed economy. There is role of interest in Islamic economic system. To redefine Islamic economic as a new economic model based on there characteristics and distinguishing regarded elements of Islamic world view. It studies about human origins, societies and cultures also deal with philosophy that deals with knowledge and include some teleological aspects. Islam has some limitations and restrictions of their own in economy as well as society .must need to understand the major different between conventional and Islamic economic must need to examine the presenting observation as well as theoretical based studies to bring legal investigations for new ideas and dimension of Islamic economics. In order to gain knowledge and experience, we have new qualitative data available to test the features, patterns and concepts of the Islamic economics. The previous year of global economic crisis to link together with failure in market different way has incense more to fonder for alternatives capable of movement toward socialism to give up completely some free market ideal. This research view is experience severe dispute especially think how the Russian society in economy expire natural instincts death as what the economy play the communist constituent political and territorial of the former nation of like china is change the way of witnessing (Aydin, 2013).

The Quran prohibit the earning of profits from one end to other unfair trading or carry out producer on based interest. Which are causing or it has harmful effects on society. The debate of them aim of Islamic economic system show that significance material possession wellbeing establish on the affecting the spiritual value constitutes require a heavy thick board of economic philosophy of Islam. The exact foundation Islamic system existence distinct from the capitalism and socialism which are both ones common places and not oriented to consisting value the super intended structure must the most common facts by different. To solve the global issues of the economy Islamic Economy play a key role to solve it. In fact the religious convictions that it is proper a representation by Muslim society to make right western misconception towards Islam. Islamic economic system show that it should not concentrated and to determine beforehand return and the scold violently of return of financial assets should be firmly resolved by immovable thing sectors. According to this study is that offering a choice is no alternative in economic to wrong the offensive state of current financing crisis and economic to accept formally and put in effect teaching of Islamic economic system carried out life in way has provided an indication and rule of human attempt change from includes economic, political, social and issue of the religion (Khwaja, 1989).

The Islamic economic system and market economy (like socialism, capitalism and mixed economy) study the material and sources in order to establish fact and prove that the lack of principals about right and wrong, uncontrolled pursuit of own interest in production as well as in consumption. Interest based system is the main and important difficulty in capitalism in contrast with mixed economy, socialism assures to bring into existence heaven on earth but it takes some basic rules of human right and financial gain in a particular way distance. In any country, Islamic economic system does not exist in its actual meaning. It is a combination of all natural characteristics exists in capitalism along with mixed economy and socialism. Capitalism economy includes 
interest because capital is scarce in the society. The main issue in distribution of income in capitalism from an Islamic point of view was only with interest. Socialism cannot insure to make every one the balanced and pay everyone the equal payment and substitute market economy in the whole sense. Socialism put an end the own action which operate separately to excel and be efficient .However mixed economy solved many problems but still there is enough space to obtain social optimum level at a grand scale somehow, mixed economy based on some features of capitalism and socialism (Sheikh, 2012).

The recent economic and financial danger in all over the world magnified the consideration of investors and other stakeholders similar on what available another possible economy can solve and set human being as a whole free from the aggression of economic confusion. Past years showed how the socialist economy of Russia unsuccessful bad, most importantly breakup of decay of united soviet socialist republic of Russia, and the supporters of communism economy of china is also facing the same destruction keeping into act of considering the continuous short break change accept to power to save the loss of reputation of the economy from complete breakdown failure. The aim of the research is to fix the Islamic system as a second choice economy that can supply lasting solution to the investing of money and economic problems. Due to hand work of men involved, capitalist, socialist and mixed economy failed. The role of interest is also considered as wicked sinful which man himself consider as of all sinful. The research make favourable suggestions that should be employed at all levels of economic activities. The capitalist economist him selves convince that the capitalist economy and money economy cannot take then to elsewhere, while the socialist economy is also died and the mix economy is facing serious serve challenges in keeping its economic problem(farisi \& rahaman, 2012).

The Comparative Economic system is capitalism, socialism unlike Islamic Economic system consideration the capital as a separate factor of production vale of an individual factor payment in interest and main issue distribution of income in the society. It serve as a foundation for capitalism to advantage from wealth of accumulation outside or lacking having to return to for good and service factor. It this particular role of interest has an extensive to exercise influence on allocation of resources. The relating to criticism the different way it is apply as market system has to a large extent allowed and provided lawful $\mathrm{d}$ statutory cover to fixed exploitive organization Economic system and their influences based on free philosophy Marx represents socialism having a unique effect historical phase that replace capitalism economy as a system a precursor to social organization in which goods are held uncommon market system socialism not to do something specified or premise to cause to exist every one equally right and well off in system term and discharge individual equally wages and replace market economy in a complete meaning. Mixed economy is a settlement of different reached by mutual concession between socialism and capitalism point of view. Mixed economy takes best use or service features of one as well as another. Some mixed economics can be tilting more capitalism and socialism followed based on social in problem relation to consumption and production in system. In any economy some fact the fault finding analysis of mixed economy through solution for free markets but it silent lacks on relating to ethics foundation to affording social attainment of the best value development economy. An 
Islamic economic system but complexly and covering doctoring. A complied tenet is not just one distinctive phase of involved in it (Shaikh, 2009).

The economic system in Islam by absolute constructions solves the issue to relation of diverse level of standards of living and income. It does not allow the wealth of the state to be solution in handle the problem on Islamic economic system. The nation can de control of the rich so exceeding what is needed or normal surplus should have be attain effort from them. It advocates of moral of system distribution of wealth with a view to accomplish a society but no accumulation of wealth should be more herds does not hoarding and there is profiteering is not involved in any business based on Islam. A society wealth is first of the economic system frame work of Islam eliminate with poverty balanced of rich and poor in a society. Islamic economic having sufficient solves the worldwide economy issue. To make clear the effect should not have interest rate of the nation it find that interest surrounding will is no necessity to economy of the hoarding to interest to be equilibrium. The market economy testimonies in way major alternative failures to yield relating answer to economic challenges and issue the economy. Most of economist thinks that were usually pleasing on writing effectively and a false idea that show the backwards of human the use of the intellect challenging. How the authority is use being endorsed as advice to mankind. The capitalism economy does not take someone socialism economy is expire material for facing various challenging in direct the attention economic system problem and issue relation to this system. The economic system in Islam means of financing treated will provided owner ship and justice wealth in term of this system in economy (Nomani \& Rahmena, 1994)

\section{KEYNESIAN ECONOMICS AND ITS FLAWS}

We all are aware with the fact of Keynesian economics facing great challenge of redeployment of wealth and how the affluence should be distributed what ways should be embraced in order to protect the economies from upcoming financial crises. In this regard Islamic views have catered to solve the challenges of inequalities within individuals as well as nations. Islam has provided the significant way for redeployment of wealth name as ZAKAT it is the best way to redistribute the affluence among the people, as it is not persuading in nature, the word zakat means purification of wealth. Whereas in monetarist economics the tool which is use for redeployment of wealth is tax, and it is a common behaviour of people that they don't pay it willing as they are not satisfied with the fact that from where there money is being utilized, due to the absence of satisfaction many people prefer to evade their self from the payment of taxes, however in zakat system people are not restricted to pay their zakat to the government only and then the state will channelize the funds which has generated with the help of zakat, in this system people are free to pay it by themselves also. Subsequently it brings positive affects in the society as the chances of accumulation of wealth within the certain class of people automatically reduce, and the economy has platform to grow as with the help of such system poverty starts to reduce (Muhammad, Usman, Majid, \& Lakhan, 2013). 
Keynesian economics has strongly focused on liberty of people, materialism individual interest, such type of system only creates disturbances in any economy, which has been proved by its practice, as this system talks about materialistic views and in this way everyone tries to achieve their own desires and no one cares about other people of the society, materialistic approaches of people strongly become cause of creating societal imbalance as mentioned earlier in detail, through such practices social interest has been neglected badly, if everyone becomes engage in the achievement of their own interest so who will cater the social interest? Keynesian economics answer this question that the social interest can be achieved with the practice of self-interest. Tool for achieving social interest is competition. It has not been proved successful because it doesn't exist in the world, because all producers want to make profit as much as they can and for achievement of this producer prefer to sale at higher prices. It has been proved that self-interest doesn't achieve social interest. It is the great cause to the failure of Keynesian economics; there are many other causes which have been discussed previously.

In taking account that Prophet Muhammad's message was to improve behaviour in the moral principles of human beings at a time of making profit and lack of knowledge of some basic principles of human rights, the religion of Islam is ever closely connected to our modern lifestyle circumstances of reduced activity, crisis of banks, materialistic nature of consumer and self interest. This case study justifies the characteristics of Islamic economic system.

\section{DOES ISLAMIC ECONOMICS HAVE POTENTIAL TO WINKLE OUT THESE FLAWS?}

It has been become the great urge of the world to have an economic system which can remove the flaws of the monetarist economics. Islamic system has potency to remove them. The main cause of failure of the former system is self-interest, whereas Islamic economic system prevent the society from all evil factors like materialism, own interest. As it teaches about sacrifice that individual should keep their interest inside the social value. Here it can be accept that sense of sacrificing leads towards the prevention of social interest. Islamic economic system has also given the solution for affective distribution of wealth, it uses one of the basic principal of Islam that is zakat, many economies are failed to fulfil the dream of distribution of affluence by adopting strict policies, where Islam doesn't in favour to compel other to contribute in for the well-being of society. Now the difficulty is why people will prefer to sacrifice their own interests for the betterment of others? In this regard Islam provides number of encouraging guidelines for doing so, and it has been also observed that few of the guidelines has given by conventional economics too, detail of the guidelines are discussed below.

One of them is competition which is to be considered as the essential element of the market strategy, for instance if a producer doesn't assure the production of standard goods at competitive prices, so such producer will be fling out from the market and 
face losses such threat bound the producer to produce standard goods at the affordable prices, which ultimately support to keep the self-interest monetized.

Besides above elaborated guidelines, good governance also play significant role to make the self-interest moneterized, as conventional economics adopted the laissez faire, which support the notion of zero government i.e. no role of government and market will be operated under market forces which are demand and supply, we know that without practicing of check and balance everyone prefer to serve their own interest for instance producer will prefer to earn more and more profit by charging goods at higher price. In its result concept of zero government has collapsed and proved that indicative check and balance and monitoring is really important by the state.

In order to reduce the challenges and flaws of Keynesian economics Islam provides the method of moral practices now the ambiguity is what does it mean and how it would be introduced in the economics. Moral values impose some obligations on earning ways of a person, that is one must earn through lawful means not by unlawful means that is by fraud, gambling, smuggling etc.

Now the question has aroused that how the Islam is playing role in the age of globalization, as many misunderstanding have been created after the event of $9 / 11$ we are already well aware about the teachings of Islam, that Islam gives the lesson of peace and harmony, it promotes trade, as these teaching has been given by many Prophets in the different time periods, as ALLAH send the new Prophet when the teachings of previous prophets had been distorted or amended by the people of the society. To be concise Islam has already taught about globalization, means promotion of cooperation, harmony and peace.

The dream of globalization can only be achieved by economic desegregation, as it promotes collective reliance which reduces the chances of conflicts and disputed at the world level, as more the collective reliance promotes lesser will be the chances of war5, and in its result development takes place, as Ibn-e-Khuldun suggested that growth doesn't takes place with keeping believe on luck, indeed it relies on economic activities.

Globalization has proved helpful for the expansion of market which brings benefits for both trading nations, in this connection Islamic economic promotes economic desegregation as explained earlier the more will be the collective reliance the less will be the possibility of disputes, it means Islam also talks about federating of making, but in today's world the dream of globalization is being achieved by liberalization, it has completely neglect he side of equality and justice. With the help of economic systems we can achieve the dream of globalization also, but it has been observed that with the help of conventional economics it wouldn't be possible as it contains great flaws and due to which this system has proved unable to achieve the objective. As conventional economics has strong focus on materialism, and we know that the materialistic approaches only promote the achievement of self-interest, because everyone become busy with fulfilling materialistic needs and consequently social interest has been neglected badly, in such environment globalization cannot be done, because globalization itself enunciates 
about cooperation peace and harmony.

Another weakness of conventional economics is it has focused on economic variables like it has completely disregarded the role of other factors which contains great impotence in prejudice the human behavior for instance moral, psychological, social and political. It means that the behavior of human being doesn't get affected by demand, supply and prices. In this support there are number of experiences of many economist which had also stressed on considering the other factors. As conventional economics describes that prices of the market are determined by demand and supply and they play vital role for the allocation of resources affectively. Here this economic system neglected the role of equity. However this system argues that once the efficiency has achieved, automatically equity will also be achieved. Ibn-e-Khaldun, the father of modern economics 600 years ago introduced a system which includes all the variables of economics, through which we can achieve efficiency and equity together.

After the above given explanation the question has aroused can Islamic economic system can overcome all the above discussed weaknesses of the system, as traditional economics has focused on self-interest and market strategy in order to solve flaws of the former discussed system. The reply of this question is negative means Islam doesn't deny the role of self interest and the market strategy in the economic growth. Though it provides ways which cover up their weaknesses which has proved unable to achieve the objective of individual interest along with social interest. Islam has given great effort to encourage the people to confine their own interest within the circumference of social interest, and this teaching requires the element of sacrificing. Now the difficulty is why will people prefer to sacrifice their own interests for the sake betterment of others? In this regard Islam provides number of encouraging guidelines for doing so, and it has been also observed that few of the guidelines has given by conventional economics too, detail of the guidelines are discussed below.

In case of lacking on the part of harmony and cooperative circumstances disputes and conflicts appears which ultimately become cause for destruction and in such worst circumstances only developing countries suffers as they use their already scant resources on the war and conflicts.

Capitalism reflects the western view that's why it describes about materialistic views, whereas Islamic economics depends on the QURAN, HADITH and views of MUSLIMS SCHOLARS. Islam doesn't only concern with the spiritual and religious life it gives complete directions for prosperous life, for this worldly life and the hereafter. In QURAN many times the word falah has been used even we listen this word in our daily life in Azan.

Conventional economics answered the three main questions that are What to produce?

How to produce? And

Whom to produce?

In the light of materialistic way, whereas the Islamic economic system answer these questions under the both worldly which pertains to human and divine or spiritual 
guidance, which has covered all the lankness's of former two economic systems. It has been noticed that in all these systems similarity prevails as they all answer the same questions but the way of answering is different.

\section{CONCLUSIONS}

In this report we have analyzed on the different aspects of Islamic economic system. What are the different goals, norms and values of that system? And from how we are able to get the profit while working in this system.

Different types of draw bags have seen in the traditional economic system, but in this new system the positive point that will help us for the better growth of the economy have a higher and strongly influence on the negative aspects.

The main goals of this system have been discussed. And by just go through it we are able to fulfil the basic and advance need of the economy. Without interest how we are able to get the profit and what different types of new loan system that is RIBA free and helpful for getting the good profit. How economy will eliminate the poverty level from the society? We have already seen that in Malaysia how new model is effective. And what changes may prevail just because adopting the new model in Malaysia.

It further more concluded that the Islamic economic system can successfully achieve the dream of globalization, as it doesn't obtain any kind of drawbacks and flaws which brings frustration and disputes in the environment. Islamic economics considered all the economic variables it doesn't look only at market and price system their system will take time to start working as full flashed economic structure in every financial sector of the Muslims countries as well as non-Muslims countries, as it has solved the hindrances and obstacles of formerly introduced systems, that's why until now it has been considered as sub-economy rather than an economic system, however it has been observed that whe4never it will be implemented as a new economic model, as this system has potency to winkle out the flaws of formerly practicing system, though it requires great effort in order to apply it, as any economic system before its application needs research, experiments and data evaluation through which economist become able to apply it is the great responsibility of Muslims scholars and Muslim economist to play vital role for this new model. Furthermore is that it will not be only beneficial for the Islamic countries but also for non-Muslim countries, since the need of such system has been realized at the international level.

But now a days non-classical economic is being using but there are some differences in concepts that is changed. In Islamic economic system the private property is being debatable. Government or state should be involved in only condition if market is failed to provide public good and education. In Islamic economic system there is not a new concepts arises the previous concepts which are already written in the QURAN is followed. If we follow these concept honestly than our economy will grow effectively. 


\section{REFERENCE}

Asutay, M. (2007). A Political Economy Approach to Islamic Economics: Systemic Understanding for an Alternative Economic System. Kyoto Bulletin of Islamic Area Studies, 3-18.

Aydin, N. (2013). Redefining Islamic Economics as a New Economic Paradigm. Islamic Economic Studies, 21(01), 1-34.

farisi, S. u., \& rahaman, A. (2012). ALTERNATIVE ECONOMIES AND ALLOCATION OF INVESTMENT IN GLOBAL MARKETS:S. Kuwait Chapter of Arabian Journal of Business and Management Review, 2(4), 60-68.

Ismail, A. G., \& Arshad, N. C. (2009). The Development of Islamic Financial Instruments. (No WIEF0902 full paper).

Khwaja, J. (1989). The Concept of the Islamic Economic System.

Moisseron, J.-Y., \& Teulon, F. (n.d.). Are Moral Islamic Economics an Answer to the Global Financial Crisis ? (2014-152).

Muhammad, A. H. (1975). Economic System in Islamic Compared with Capitalism. In A. H. Muhammad, Economic System in Islamic (Vol. 2nd Edition). Tehran, Iran: World Organization for Islamic Services,.

Muhammad, S. D., Usman, M., Majid, A., \& Lakhan, G. R. (2013). Distribution of Wealth an Islamic Perspective: Theoretical Consideration. World Applied Sciences Journal, 23(8), 1118-1124.

Nomani, F., \& Rahmena, A. (1994). Islamic economic systems. In Critique: Critical Middle Eastern Studies (Vol. 2, pp. 79-82). London: London: Zed books.

Rahim, S. A. (2011). Inherent Islamic Values in the New Economic Model of. Malaysia. FEB Working Paper Series No. 1106, 1-15.

Shaikh, S. (2009). A Comparative Study of the Major Economic Systems in the aftermath of the Great Recession. Munich Personal RePEc Archive. Retrieved from http://mpra.ub.uni-muenchen.de/19588/

Sheikh, S. (2012). Comparative Economic Systems: A Brief Review. Munich Personal RePEc Archive. 